\title{
Management of knowledge-intensive organizations: what do we know after twenty years of research?
}

\begin{abstract}
During the past twenty years a vast amount of academic work has been done in the area of managing knowledge-intensive organizations. Due to the large volume and dispersed nature of prior research it is difficult to gain a holistic view on what is actually known about this issue. This study synthesizes the discussion on the management of knowledge-intensive organizations. A literature review was conducted to cover two research questions: first, what are the key characteristics of knowledge-intensive organizations and knowledge work, and second, what are the main managerial issues that originate from the nature of knowledgeintensive organizations? The review makes a contribution by forming a comprehensive view of the key issues involved in managing knowledge-intensive organizations. As its pragmatic outcome the paper provides a managerial checklist that helps to recognize some of the key aspects that are relevant in managing knowledge-intensive organizations.
\end{abstract}

Keywords: knowledge-intensive organization, service, knowledge management, intellectual capital, intangibility, knowledge assets, knowledge work, management, value creation, literature review

\section{Introduction}

During the recent decades the developed countries have witnessed a major shift from an industrial manufacturing dominated economy to a more knowledge-based and service-oriented one (Lönnqvist, 2011; Tomé, 2014). The emergence of knowledge as a key driver of competitiveness and autonomous knowledge workers as the dominant class of employees have meant new challenges for managers. It seems obvious that the traditional manufacturing-based management thinking does not match the new context (Davenport, 2008).

Many management scholars acknowledged the ongoing transformation in the 1990s. The general management literature paid attention to the growing importance of knowledge as a resource for competitive advantage and to the specific challenges associated with managing knowledge, knowledge workers and knowledge-intensive organizations. For example, Drucker (1999) argued that knowledge work productivity is the greatest management challenge of $21^{\text {st }}$ century organizations.

During 1990s, the academic discipline of knowledge management - a specialist discipline focused on the management challenges of the knowledge era - was also beginning to take shape. Several seminal research articles and knowledge management books were published in the mid90s (e.g., Nonaka, 1994; Sveiby, 1997). During the first decade of the $21^{\text {st }}$ century several new knowledge management journals and conferences were launched. Consequently, the knowledge management discussion separated into smaller sub disciplines (e.g., information management, 
intellectual capital, organizational learning, and knowledge-based development) which examined different aspects of knowledge and its management (Carrillo et al., 2014). The amount of knowledge management research grew and produced a great quantity of academic knowledge on the topic.

After the rapid growth of knowledge management research, it now seems that a kind of a stabilization (or even decline) in the interest towards knowledge management is taking place. In the early phases, knowledge management was considered a necessity for most organizations and especially for those operating in a knowledge-intensive business (Wiig, 1997). However, after the main boom it seems that the evidence for the argued benefits of knowledge management remains quite thin (Inkinen, 2016). This has raised discussions concerning the relevance and added value of knowledge management as a discipline (Bailey and Clarke, 2000; Booker et al., 2008; Serenko and Bontis, 2011).

One of the potential causes for the lack of evidence reported in the literature is the disintegration of the research field (Maier and Remus, 2003). The scholars dedicated to the above-mentioned sub disciplines of knowledge management focus on their particular perspectives while other management scholars, for example, in the areas of strategic management, human resource management or regional development have their own perspectives and discourses. Thus, despite, or because of, the vast amount of academic work done in the area of managing knowledge-intensive organizations, it is difficult to gain a holistic view on what is actually known about this issue.

This conceptual paper aims to synthesize the fragmented discussion on the management of knowledge-intensive organizations. In order to reach this objective, we carried out an extensive literature review covering both knowledge management journals and articles published in general management journals that deal with the management of knowledge-intensive organizations. Our literature review was guided by the following research questions: First, what are the key characteristics of knowledge-intensive organizations and knowledge-intensive work (or knowledge work)? Second, what are the main managerial issues that originate from the nature of knowledge-intensive organizations?

In order to identify relevant articles from the huge amount of potential literature, we first identified several studies focusing on the core management issues of knowledge-intensive organizations. Based on reviewing those we decided to focus our research on three themes that emerged out of the literature: 1) knowledge as the key driver of value creation, 2) knowledge workers as key actors in knowledge-intensive organizations and 3) the service-orientation of knowledge-intensive activities. Focusing on these three themes allowed us to further guide our literature search and to deepen our review of the chosen perspectives. The results of the review are reported in the following sections by first focusing on one perspective at a time and then providing a synthesis in the end.

As its main outcome this paper produces a structured interpretation of what is known about the management of knowledge-intensive organizations. In addition, we will recognize future research areas related to the management of knowledge-intensive organizations. The contribution of this paper is based on reviewing a very dispersed and large amount of literature 
on the topic and condensing the information into a compact and comprehensive view of the research theme.

\section{Dealing with knowledge - the key source of organizational performance}

Knowledge-intensity is a characteristic of an organization that operates using knowledge as its main value driver in contrast to capital or labor (Starbuck, 1992). According to Miles et al. (1995), knowledge-intensive organizations' key activities include the creation, accumulation and dissemination of knowledge. Knowledge-intensive organizations have the capacity to create novel solutions to complex problems (Sveiby, 1997). In the literature, there are various ways to classify and categorize knowledge-intensive organizations (e.g., Winch and Schneider, 1993; Von Nordenflycht, 2010; Käpylä et al., 2011). There are also many ways to characterize knowledge-intensive organizations. Typical features that can be associated to knowledgeintensive organizations include the ambiguity of activities (Alvesson, 2001), innovativeness (Horgos and Koch, 2008), intangibility (Ditillo, 2004), the importance of tacit knowledge (Muller and Doloreux, 2009; Windrum and Tomlisson, 1999) and technical complexity and sophistication of the solutions provided (Morgan-Thomas and Jones, 2009).

The theoretical foundation of knowledge-based value creation lays in the resource-based theory of the firm, which tries to understand and explain how internal resources contribute to organizations' sustainable competitive advantage (Barney, 1991; Kraaijenbrink et al., 2010). Its follower, the knowledge-based view (KBV) stresses the importance of knowledge resources and conceptualizes the firm as an institution for integrating knowledge (Grant, 1996; Spender, 1996). Therefore, knowledge can be seen as the key value driver for an organization. Moreover, it can also be seen as the source of development for cities, regions and nations (e.g., Lönnqvist and Laihonen, 2013; Schiuma and Lerro, 2011; Yigitcanlar, 2011).

In order to be able to deal with knowledge a specific research stream of knowledge management evolved in the mid 1990's to help organizations to out-perform competitors (Chaharbaghi and Lynch, 1999; Mahdi et al., 2011; Schiuma, 2012). The knowledge management discipline aimed to improve performance by stressing the importance of knowledge creation, development, organization and leveraging (Wiig, 1997). These knowledge processes are considered critical for the success of knowledge-intensive organizations. Another parallel research stream, intellectual capital management, evolved for examining more comprehensively the different types of knowledge-related assets as strategically important resources and value drivers (Lev, 2001; Schiuma et al., 2007; Sveiby, 1997). Over the years both streams have produced a lot of conceptual and managerial frameworks for managing knowledge. These frameworks can, for example, help managers to recognize in their thinking that knowledge is a highly important value driver (Amadasun, 2014).

Due to their characteristics, knowledge and knowledge assets more widely are problematic from a managerial perspective. For example, they are intangible in nature, which makes it difficult to measure their status and development (Lev, 2001). Another typical management challenge is to be able to codify tacit knowledge (to the extent that is possible) in order to make it easier 
to transfer (Walsh, 2014). It is also a challenge to protect the valuable assets and the associated services from falling into the hands of competitors (Amara, 2008). Nisula and Kianto (2014) point out that service organizations should be able to renew their knowledge and knowledgebased value creation processes in order to remain competitive.

Another important issue is that there are many ways to utilize knowledge assets as a source of competitiveness (Autio et al., 2000; Käpylä et al., 2011). In other words, the question is not only about possessing valuable knowledge assets but transforming them into competencies and capabilities and ultimately to successful business (Løwendahl, 2001; Laihonen and Lönnqvist, 2011). Knowledge-intensive organizations have different strategies for value creation, the extreme ends being customization and standardization (Bettiol et al., 2015).

To summarize, knowledge, and knowledge assets more widely, represent the basis of value creation for knowledge-intensive organizations. However, due to their nature those are difficult to manage. In the literature, there are several managerial frameworks available to help overcome these challenges. Some of the key management questions include the following:

- what are the strategically most relevant knowledge assets in a particular case?

- how are they acquired, protected and further developed?

- what kind of a strategy and business model is used to transform the knowledge assets into customer value?

\section{Managing knowledge workers}

Knowledge-intensive organizations are widely considered as people organizations (e.g., Alvesson, 1993; Blackler, 1995; Starbuck, 1992; Winch and Schneider, 1993; Käpylä et al., 2011). Thus, knowledge work conducted by an individual knowledge worker is a key component of knowledge-intensive organizations and the high significance of human capital is a key distinctive feature of knowledge-intensive organizations (Von Nordenflycht, 2010).

Pyöriä (2005) states that knowledge work is based on a high level of education and skills and the use of information technology is an integral part of the informational labour process. According to Davenport et al. (1996, p. 54), "Knowledge work's primary activity is the acquisition, creation, packaging, or application of knowledge". One of the key characteristics of knowledge work is autonomy (Drucker, 1999). Knowledge workers are highly skilled professionals who are expected to work independently and make decisions regarding their work.

The autonomous nature of knowledge work has several implications for management. First, the individual worker or work team should be allowed to make decisions by themselves and plan their work according to their best judgment. Second, in order to make good decisions they should understand very well what their task and objective is (Drucker, 1999). Third, the overall work setting should be such that knowledge workers are highly motivated to carry out their duties. Otherwise, it is unlikely that they will be efficient and effective. Thus, developing adequate incentives is an important managerial task (Belfo, 2014), although a challenging one (Nicholson, 2003). 
The literature on knowledge workers has focused on the actual work at individual and team level, and highlights the importance of objectives, purpose of work and provides various means to improve knowledge work (e.g., Davenport, 2008; Dove, 1998; Drucker, 1999; Janz et al., 1997; Miller, 1977). Still, many organizations struggle with finding the most applicable ways of improving the performance of knowledge work. This is mainly because both inputs and outputs of knowledge work are intangible and difficult to define and the work process itself can be fuzzy (Davenport, 2008; Bosch-Sijtsema et al., 2009; Laihonen et al., 2012). In knowledge work, the quality of the outputs is more important than the quantity of the outputs (Drucker, 1999). Moreover, the final outcomes may take a long time to develop and the value of the outcome can be estimated only when used by the customer (Bosch-Sijtsema et al., 2009). Because of these features the productivity of knowledge work is typically very difficult to capture (Ramirez and Nembhard, 2004).

Managing and improving knowledge work performance can be approached not only from the perspective of task performance as such but it can focus also on contextual factors such as work community, facilities, technological equipment, personal relationships or working atmosphere (Amabile, 1998; Ferris et al., 2001; Goodman and Svyantek, 1999; Kahya, 2008; Ropo et al., 2015). For example, Palvalin et al. (2013) have studied the impact of ICT on knowledge work productivity. Similarly, Peponis et al. (2007) and Ruostela et al. (2015) have explored the role of facilities and spaces for knowledge work performance. The variety of potential solutions is significant and the individual manager easily confronts a challenge of finding the most suitable approach for his/her organization.

Recently, many novel approaches have been proposed to improve the performance of knowledge work. For example, the 'new ways of working' philosophy starts by actively questioning the usefulness of existing work practices and explores more flexible and "smart" ways of working (Ruostela et al., 2015). Staats and Upton (2011) have proposed the use of lean management principles in knowledge work context. Others have promoted more radical organizational models to accommodate the nature of knowledge work. An example of such is 'holacracy', which refers to non-hierarchic and autonomous type of organizing work (Bernstein et al., 2016).

To summarize, knowledge workers form the core of a knowledge-intensive organization. Due to its nature, knowledge work is not easy to manage. In fact, to some extent, the knowledge workers themselves are expected to manage their work while the formal management has the role of making sure objectives are understood, the working environment supports work processes and that the workers remain motivated.

\section{Knowledge-intensive organizations as service organizations}

In many cases, knowledge-intensive organizations produce services in contrast to manufacturing goods. There is a big variety of knowledge-intensive services in consumer and business-to-business markets as well as in the public and non-profit sectors. According to Vargo and Lusch (2004), 'service' is about the application of specialized skills and knowledge for the benefit of the customer. In the context of service, value is co-created by both the service 
provider and the customer (e.g., Eichentopf et al., 2011; Gummesson, 1998; Grönroos and Ojasalo, 2004; Heinonen et al., 2010). For example, knowledge-intensive service organizations create new knowledge together with the customer (Walsh, 2014).

The challenges of service management (Gummesson, 1998) and service operations management (Johnston, 1999) originate from the IHIP (intangibility, heterogeneity, inseparability, perishability) characteristics of services (Berry and Bendapudi, 2007). They are discussed extensively in the service management literature and thus reviewed only briefly here.

A major challenge of service management relates to the intangibility of services. According to Tarn (2005), intangibility-related management problems include the following: intangibility 1) makes customers feel a high sense of risk and uncertainty, 2) makes it difficult for customers to form expectations regarding the service, 3) produces heterogeneity among customers' expectations and 4) makes customers seek information via their interpersonal sources and avoid brand switching. Laihonen and Lönnqvist (2010) have examined knowledge-based value creation in service context and recognized several commonalities between the disciplines of service management and intellectual capital management with regard to the managerial problems cause by intangibility. For example, there are similar difficulties in measuring intangible service outputs (e.g., Chiu and Lin, 2004; Flipo, 1988; Jääskeläinen and Lönnqvist, 2009) as there are in measuring the intangible assets such as skills and competences that are key value drivers in service organizations.

The customer's continuous presence in the value creation process is another source of managerial challenges. Service is typically considered as an 'open process' and the customer is its key evaluator (Johnston and Clark, 2005; Grönroos and Ojasalo, 2004). For this reason, the management's focus needs to be widened from an internal or producer perspective towards a more comprehensive and external view of value creation (Brignall, 1997; Johnston and Clark, 2005). For example, performance measurement practices should cover customers' actions during the service operation as well as the impacts of service operations (Jääskeläinen et al., 2014; Jääskeläinen, and Laihonen, 2013). Issues such as customer-perceived value (Grönroos and Ojasalo, 2004; Parasuraman, 2002) and service quality (Chowdhary and Prakash, 2007; Parasuraman, 2004) are particularly relevant in knowledge-intensive organizations because of the high level of intangibility of activities (Laihonen and Lönnqvist, 2010).

The networked nature of service production poses yet more management challenges. This has been widely studied in most management disciplines. It has been discussed, for example, in supply chain management (e.g., Gunasekaran et al., 2004; May et al., 2014; Selviaridis and Norrman, 2014), knowledge management (Easterby-Smith et al., 2008; Hutzschenreuter and Horstkotte, 2010; Jalonen, 2013; Martinkenaite, 2011; Phelps et al., 2012; van Wijk et al., 2008), and performance management (Gunasekaran and Kobu, 2007; Nudurupati et al., 2011; Bititci et al., 2007). These all highlight the complexity of value creation processes and their collaborative and interactive nature. Therefore, Vargo et al. (2008) suggest a service systems approach to these value-creation configurations. The approach centers on the participants, processes, and resources that interact to create value (Vargo et al., 2008). Especially relevant for knowledge-intensive organizations is the argument from Fjeldstad and Haanæs (2001) that 
value creation in a value network does not lie in transforming objects per se, but in their mediation. The strength of a value network originates from co-operation and interaction among participating organizations (Peltoniemi, 2004). A key question regarding this issue is who has the legitimacy to manage these networks or service systems consisting of independent organizations.

To summarize, knowledge-intensive organizations are not only knowledge-intensive but also service organizations. The service aspect brings along its own managerial questions. Especially the active role of the customer and the (often) networked nature of value creation activities widens the managerial landscape outside the organization to include customers' action and the overall process in the service system. Intangibility is also strongly present in service activities.

\section{Discussion and conclusions}

Our literature review confirmed the original proposition of this study: there is a big variety of literature on the management of knowledge-intensive organizations and it is not easy to obtain a comprehensive view of the issue. The review explored the management of knowledgeintensive organizations from three perspectives: 1) the nature of knowledge knowledge-based value creation, 2) managing autonomous knowledge workers and 3) the service-orientation of activities. Figure 1 provides a comprehensive view of the main characteristics of knowledgeintensive organizations and lists examples of the associated management issues.

\section{<< INSERT FIGURE 1 HERE $\gg>$}

The main idea in Figure 1 is to highlight that knowledge-intensive organizations have different characteristics, which all have their own implications to management. The dispersed academic literature is usually focused only on a very narrow view of the whole issue. For example, knowledge management articles provide useful information to capture some of the management questions related to the knowledge-based value creation perspective while neglecting the other perspectives. Our review demonstrated that the management of knowledge-intensive organizations is not only about managing knowledge - it is also about dealing with knowledge workers, customers, the wider service system and all the challenges associated to each. Therefore, we feel that this review makes a contribution by forming a comprehensive view of the key issues involved in managing knowledge-intensive organizations.

The main objective of this paper was to summarize what is currently known, after roughly twenty years of research, about the management of knowledge-intensive organizations. Sections 2, 3 and 4 provided answers from the three main perspectives covered in this paper, so they are not repeated here. Instead, the core findings are stated in the form of guidelines for managing knowledge-intensive organizations:

1. An important starting point is that the management should acknowledge the important role of knowledge as the key value driver for modern business. This sensitivity towards 
knowledge-based phenomena guides managers' actions and helps keep these intangible phenomena on their agenda.

2. Knowledge is a challenging management object but there are plenty of management frameworks and practical tools available in the literature that can help managers cope with it.

3. It is vital to understand that although knowledge is regarded as an important value driver, just having knowledge does not automatically lead to success. The key is the business model that transforms the knowledge assets into outcomes valued by the customer.

4. Autonomous knowledge workers should understand the objectives of their work thoroughly in order for them to be able to make sound decisions and to find meaningfulness in their work. The role of management is important in setting and communicating about the objectives.

5. Knowledge workers should be allowed to choose the ways of working they feel best fits the task at hand and the working style of the person in question. This relates to both the effectiveness and the experienced meaningfulness of work tasks.

6. Managers should focus their attention to the desired outcomes of work and evaluate employees in relation to them - not in relation to input factors or the way work has been done.

7. Service value and the outcomes experienced by the customer are among of the most important organizational goals. In order to capture the value of knowledge-based service activities, managerial attention needs to extend to cover the actions of the customer and the wider service system.

8. Continuous learning and renewal of individual and organizational practices and processes is necessary in a constantly evolving environment. A proactive attitude in questioning the existing ways of doing things is valuable.

The list above is, naturally, not comprehensive. There are countless context-specific management issues that are not included. Similarly, there may be situations in which these guidelines are invalid. Nevertheless, we feel that such a list may be useful as a checklist for acknowledging some of the key aspects that are relevant in managing knowledge-intensive organizations.

Our review shows that there is a lot that we already know based on earlier research about the management of knowledge-intensive organizations. Nevertheless, several avenues for future research can be identified. One of these relates to the fact that the management practices of knowledge-intensive organizations are currently evolving at such a fast pace that empirical research has difficulties in keeping up. Systematic and long-term evaluation of new practices is required in order to understand their value and limitations. For example, 'New ways of working', 'lean knowledge work' and 'holacracy' are new approaches which require more thorough research. An even bigger research challenge is brought by digitalization. This phenomenon is transforming industries and making many knowledge-intensive processes and work tasks redundant. On the other hand, digitalization is likely to create totally new tasks as well. This theme offers many intriguing research questions. For example, how do knowledgeintensive organizations meet the forthcoming disruption brought by digitalization; what strategies do they use to prepare for the threats and to capture the opportunities? Even though a lot of research has already been done the continuing evolution of knowledge-intensive 
organizations and their environments will most probably keep this topic as a relevant research theme also for the next twenty years.

\section{References}

Alvesson, M. (1993) 'Organizations as Rhetoric: Knowledge-Intensive Companies and the Struggle with Ambiguity', Journal of Management Studies, Vol. 30 No. 6, pp.997 - 1015.

Alvesson, M. (2001) 'Knowledge Work: Ambiguity, Image and Identity', Human Relations, Vol. 54 No. 7, pp.863 - 886.

Amadasun, P. (2014) 'Application of organisational homeostasis as an emerging paradigm for knowledge management', International Journal of Knowledge-Based Development, Vol. 5 No. 1, pp.32 - 49.

Amabile, T. M. (1998) 'How to Kill Creativity', Harvard Business Review, Vol. 76 No. 5, pp.77 $-87$.

Amara, N., Landrya, R., Traoréb, N. (2008) 'Managing the protection of innovations in knowledge-intensive business services', Research Policy, Vol. 37 No. 9, pp.1530 - 1547.

Autio, E., Sapienza, H. J. ja Almeida, J. G. (2000) 'Effects of Age at Entry, Knowledge Intensity, and Imitability on International Growth', Academy of Management Journal, Vol. 43 No. 5, pp.909 - 924.

Bailey, C. and Clarke, M. (2000) 'How do managers use knowledge about knowledge management?', Journal of Knowledge Management, Vol. 4 No. 3, pp. 204 - 216.

Barney, J. (1991) 'Firm Resources and Sustained Competitive Advantage', Journal of Management, Vol. 17 No. 1, pp.99 - 120.

Belfo, F. (2014) 'Organisational and staff development: a virtuous cycle in the knowledgebased economy', International Journal of Knowledge-Based Development, Vol. 5 No. 1, pp. 17 - 31.

Bernstein, E., Bunch, J., Canner, N., Lee, M. (2016) 'The big idea beyond the holacracy hype. The overwrought claims-and actual promise-of the next generation of self-managed teams', Harvard Business Review, July-August 2016, pp.38 - 49.

Berry, L., L. and Bendapudi, N. (2007) 'Health care: a fertile field for service research', Journal of Service Research, Vol. 10 No. 2, pp.111 - 122.

Bettiol, M., Di Maria, E., Grandinetti, R. (2015) 'Service customisation and standardisation in combinatory knowledge-intensive business services', International Journal of KnowledgeBased Development, Vol. 5 No. 1, pp.241 - 260.

Bititci, U., Garengo, P., Dörfler, V. and Nudurupati, S. (2012) 'Performance measurement: challenges for tomorrow', International Journal of Management Reviews, Vol. 14 No. 3, pp.305 - 327.

Blackler, F. (1995) 'Knowledge, Knowledge Work and Organizations: An Overview and Interpretation', Organization Studies, Vol. 16 No. 6, pp.1021 - 1046.

Booker, L., Bontis, N. and Serenko, A. (2008) 'The relevance of knowledge management and intellectual capital research', Knowledge and Process Management, Vol. 15 No. 4, pp.235 $-246$.

Bosch-Sijtsema, P.M., Ruohomäki, V., Vartiainen, M. (2009) 'Knowledge work productivity in distributed teams', Journal of Knowledge Management, Vol. 13 No. 6, pp.533 - 546. 
Brignall, S. (1997) 'A contingent rationale for cost system design in services', Management Accounting Research, Vol. 8, pp.325 - 346.

Carrillo, F.J., Yigitcanlar, T., Garcia, B., Lönnqvist, A. (2014) Knowledge and the City: Concepts, Applications and Trends of Knowledge-Based Urban Development, Routledge Studies in Human Geography, New York.

Chaharbaghi, K. and Lynch, R. (1999) 'Sustainable competitive advantage: towards a dynamic resource-based strategy’, Management Decision, Vol. 37 No. 1, pp.45 - 50.

Chiu, HC., and Lin, NP. (2004) 'A service quality measurement derived from the theory of needs', The Service Industries Journal, Vol. 24 No. 1, pp.187 - 204.

Chowdhary, N. and Prakash, M. (2007) 'Prioritizing service quality dimensions', Managing Service Quality, Vol. 17 No. 5 pp.493 - 509.

Davenport, T. H., Jarvenpaa, S. L., Beers, M. C. (1996) 'Improving Knowledge Work Processes', Sloan Management Review, Vol. 37 No. 4, pp.53 - 65.

Davenport, T.H. (2008) 'Improving knowledge worker performance', in Pantaleo, D. and Pal, N. (Eds.) From Strategy to Execution: Turing Accelerated Global Change into Opportunity, Springer, Berlin, Heidelberg, pp.215-235.

Ditillo, A. (2004) 'Dealing with Uncertainty in Knowledge-Intensive Firms: The Role of Management Control Systems as Knowledge Integration Mechanism', Accounting, Organizations and Society, Vol. 29 No. 3-4, pp.401 - 421.

Dove, R. (1998) 'The knowledge worker', Automotive Manufacturing \& Production, Vol. 110 No. 6, pp.26 - 28.

Drucker, P.F. (1999) 'Knowledge-worker productivity: The biggest challenge', California Management Review, Vol. 41 No. 2, pp.79 - 94.

Easterby-Smith, M., Lyles, M.A. and Tsang, E.W.K. (2008) 'Inter-Organizational Knowledge Transfer: Current Themes and Future Prospects', Journal of Management Studies, Vol. 45 No. 4, pp.677 - 690 .

Ferris, G.R., Witt, L.A., Hochwarter, W.A. (2001) 'Interaction of Social Skill and General Mental Ability on Job Performance and Salary', Journal of Applied Psychology, Vol. 86, pp.1075 - 1082.

Eichentopf, T., Kleinaltenkamp, M., van Stiphout, J. (2011) 'Modelling customer process activities in interactive value creation', Journal of Service Management, Vol. 22 No. 5, pp.650 - 663.

Fjeldstad, Ø. and Haanæs, K. (2001) 'Strategy tradeoffs in the knowledge and network economy’, Business Strategy Review, Vol. 12 No. 1, pp.1 - 10.

Flipo, J-P. (1988) 'On the intangibility of services', The Service Industries Journal, Vol. 8 No. 3, pp.286 - 293.

Grant, R.M. (1996) 'Toward a Knowledge-Based Theory of the Firm', Strategic Management Journal, 17 (Special Issue: Knowledge and the Firm), pp.109 - 122.

Goodman, S.A. and Svyantek, D.J. (1999) 'Person-organization fit and contextual performance: Do shared values matter', Journal of Vocational Behavior, Vol. 55 No. 2, pp. 254 - 275.

Grönroos, C. and Ojasalo, K. (2004) 'Service productivity: Towards a conceptualization of the transformation of inputs into economic results in services', Journal of Business Research, Vol. 57 No. 4, pp.414 - 423.

Gummesson, E. (1998) 'Productivity, quality and relationship marketing in service operations', International Journal of Contemporary Hospitality Management, Vol. 10 No. 1, pp.4 - 15. 
Gunasekaran, A. and B. Kobu. (2007) 'Performance measures and metrics in logistics and supply chain management: A review of recent literature (1995-2004) for research and applications', International Journal of Production Research, Vol. 45 No. 12, pp.2819 2840.

Gunasekaran, A., Patel, C. McGaughey, R.E. (2004) 'A framework for supply chain performance measurement', International Journal Production Economics, Vol. 87, pp.333 $-347$.

Heinonen, K., Strandvik, T., Mickelsson, K.-J., Edvardsson, B., Sundström, E. and Andersson, P. (2010) 'A customer-dominant logic of service', Journal of Service Management, Vol. 21 No. 4, pp.531 - 548.

Hill, T. P. (1977) 'On goods and Services', Review of Income and Wealth, Vol. 123 No. 4, pp.315-338.

Horgos, D. and Koch, A. (2008) 'The Internal Differentiation of the KIBS Sector: Empirical Evidence from Cluster Analysis', International Journal of Services Technology and Management, Vol. 10 Nos. 2/3/4, pp.190 - 210.

Hutzschenreuter, T. and Horstkotte, J. (2010) 'Knowledge transfer to partners: a firm level perspective', Journal of Knowledge Management, Vol. 14 No. 3, pp.428 - 448.

Inkinen, H. (2016) 'Review of empirical research on knowledge management practices and firm performance', Journal of Knowledge Management, Vol. 20 No. 2, pp.230 - 257.

Jääskeläinen, A. and Laihonen, H. (2013) 'Overcoming the Specific Performance Measurement Challenges of Knowledge-intensive Service Organizations', International Journal of Productivity and Performance Management, Vol. 62 No. 4, pp.350 - 363.

Jääskeläinen, A., Laihonen, H., Lönnqvist, A. (2014) 'Distinctive features of service performance measurement', International Journal of Operations \& Production Management, Vol. 34 No. 12 pp.1466 - 1486.

Jääskeläinen, A. and Lönnqvist, A. (2009) 'Designing Operative Productivity Measures in Public Services', VINE: The journal of information and knowledge management systems, Vol. 38 No. 1, pp.55 - 67.

Jalonen, H. (2013) 'The knowledge-innovation nexus in the welfare service ecosystem', International Journal of Knowledge-Based Development, Vol. 4 No. 1, pp.34 - 49.

Janz, B. D., Colquitt, J. A., Noe, R. A. (1997) 'Knowledge worker team effectiveness: the role of autonomy, interdependence, team development, and contextual support variables', Personnel Psychology, Vol. 50 No. 4, pp.877 - 902.

Johnston, R. (1999) 'Service operations management: return to roots', International Journal of Operations \& Production Management, Vol. 19 No. 2, pp.102 - 124.

Johnston, R. and Clark, G. (2005) Service Operations Management: Improving Service Delivery, $2^{\text {nd }}$ ed., Prentice Hall, London.

Kahya, E. (2008) 'The effects of job performance on effectiveness', International Journal of Industrial Ergonomics, Vol. 39, pp.96 - 104.

Kraaijenbrink, J., Spender, J.C. and Groen, A.J. (2010) 'The Resource-Based View: A Review and Assessment of its Critiques', Journal of Management, Vol. 36, pp..349 - 372.

Käpylä, J., Laihonen, H., Lönnqvist, A. and Carlucci, D. (2011) 'Knowledge-intensity as an organisational characteristic', Knowledge Management Research \& Practice, Vol. 9, pp.315 - 326. 
Laihonen, H. and Lönnqvist, A. (2010) 'Knowledge-based value creation: grasping the intangibility of service operations in Finland', International Journal of Knowledge-Based Development, Vol. 1 No. 4, pp.331 - 345.

Laihonen, H. and Lönnqvist, A. (2011) 'How knowledge assets are transformed into value: the case of knowledge flows and service productivity', in Schiuma (ed.) Managing Knowledge Assets and Business Value Creation in Organizations: Measures and Dynamics, Idea Group Publishing Ltd, Hershey, PA, pp.173 - 187.

Laihonen, H., Jääskeläinen, A., Lönnqvist, A. and Ruostela, J. (2012) 'Measuring the productivity impacts of new ways of working', Journal of Facilities Management, Vol. 10 No. 2, pp.102 - 113.

Lev, B. (2001) Intangibles. Management, Measurement, and Reporting, Brookings Institution Press, Washington, D.C.

Lönnqvist, A. (2011) 'Knowledge-based value creation in service dominant environment', (Special issue editorial) Measuring Business Excellence, Vol. 15 No. 4, pp.1 - 4.

Lönnqvist, A., and Laihonen, H. (2013) 'Managing regional development: a knowledge perspective', International Journal of Knowledge-Based Development, Vol. 4 No. 1, pp.50 $-63$.

Løwendahl, B., Revang, Ø. and Fosstenløkken, S. (2001) 'Knowledge and Value Creation in Professional Service Firms', Human Relations, Vol. 54 No. 7, pp.911 - 931.

Mahdi, O.R., Almsafir, M.K. and Yao, L. (2011) 'The role of knowledge and knowledge management in sustaining competitive advantage within organizations: A review', African Journal of Business Management, Vol. 5 No. 23, pp.9912 - 9931.

Maier, R. and Remus, U. (2003) 'Implementing process-oriented knowledge management strategies', Journal of Knowledge Management, Vol. 7 No. 4, pp.62 - 74.

Martinkenaite, I. (2011) 'Antecedents and consequences of inter-organizational knowledge transfer - Emerging themes and openings for further research', Baltic Journal of Management, Vol. 6 No. 1, pp.53 - 70.

May, A., Anslow, A., Wu, Y., Ojiako, U., Chipulu, M. and Marshall, A. (2014) 'Prioritisation of performance indicators in air cargo demand management: an insight from industry', Supply Chain Management: An International Journal, Vol. 19 No. 1, pp.108 - 113.

Miles I., Kastrinos N., Flanagan K., Bilderbeek R., den Hertog P., Huntink W. and Bouman M. (1995) Knowledge-Intensive Business Services: Users, Carriers and Sources of Innovation, European Innovation Monitoring System (EIMS) EIMS Publication No. 15, Luxembourg.

Miller, D. B., (1977) 'How to Improve the Performance and Productivity of the Knowledge Worker', Organizational Dynamics, Vol. 5 No. 3, pp.62 - 80.

Morgan-Thomas, A., Jones, M. V. (2009) 'Post-entry Internationalization Dynamics: Differences between SMEs in the Development Speed of their International Sales', International Small Business Journal, Vol. 27 No. 1, pp.71 - 97.

Muller, E. and Doloreux, D. (2009) 'What We Should Know about Knowledge-Intensive Business Services', Technology in Society, Vol. 31 No. 1, pp.64 - 72.

Nicholson, N. (2003) 'How to Motivate Your Problem People', Harvard Business Review, Vol. 81 No 1, pp.56 - 65.

Nisula, A-M. and Kianto, A. (2014) 'Assessing and developing organisational renewal capability in the public sector', International Journal of Knowledge-Based Development, Vol. 5 No. 1, pp.98 - 115.

Nonaka, I. (1994) 'A Dynamic Theory of Organizational Knowledge Creation', Organization Science, Vol. 5 No. 1, pp.14 - 37. 
Nudurupati, S.S., Bititci, U.S., Kumar, V. and Chan, F.T.S. (2011) 'State of the art literature review on performance measurement', Computers \& Industrial Engineering, Vol. 60, pp.279 - 290.

Palvalin, M., Lönnqvist, A. and Vuolle, M. (2013) 'Analysing the impacts of ICT on knowledge work productivity', Journal of Knowledge Management, Vol. 17 No. 4, pp.545 - 557.

Parasuraman, A. (2002) 'Service quality and productivity: a synergistic perspective', Managing Service Quality, Vol. 12 No. 1, pp.6 - 9.

Parasuraman, A. (2004) 'Assessing and improving service performance for maximum impact: insights from a two-decade-long research journey', Performance Measurement \& Metrics, Vol. 5 No. 2, pp.45 - 52.

Peltoniemi, M. (2004) 'Cluster, Value Network and Business Ecosystem: Knowledge and Innovation Approach'. In proceedings of the Organisations, Innovation and Complexity: New Perspectives on the Knowledge Economy conference, NEXSUS: The Complexity Society and CRIC Centre for Research on Innovation and Competition, Manchester England.

Peponis, J., Bafna, S., Bajaj, R., Bromberg, J., Congdon, C., Rashid, M., Warmels, S., Zhang, Y., Zimring, C. (2007) 'Designing space to support knowledge work', Environment \& Behavior, Vol. 39 No. 6, pp.815 - 840 .

Phelps, C., Heidl, R. and Wadhwa, A. (2012) 'Knowledge, Networks, and Knowledge Networks: A Review and Research Agenda', Journal of Management, Vol. 38 No. 4, pp.1115 - 1166.

Pyöriä, P. (2005) 'The concept of knowledge work revisited', Journal of Knowledge Management, Vol. 9 No. 3, pp.116 - 127.

Ramirez, Y.W. and Nembhard, D.A. (2004) 'Measuring knowledge worker productivity - A taxonomy', Journal of Intellectual Capital, Vol. 5 No 4, pp.602 - 628.

Ropo, A., Salovaara, P., Sauer, E. and De Paoli, D. (2015) Leadership in Spaces and Places, Edward Elgar, Cheltenham, UK and Northampton, MA, USA.

Ruostela, J., Lönnqvist, A., Palvalin, M., Vuolle, M., Patjas, M. and Raij, A.-L. (2015) 'New Ways of Working' as a tool for improving the performance of a knowledge-intensive company', Knowledge Management Research and Practice, Vol. 13 No. 4, pp.382 - 390.

Schiuma, G. (2012) 'Managing knowledge for business performance improvement', Journal of Knowledge Management, Vol. 16 No. 4, pp.515 - 522.

Schiuma, G., de Pablos, P.O. and Spender, J.C. (2007) 'Foreword: Intellectual Capital and Company's Value Creation Dynamics', International Journal of Learning and Intellectual Capital, Vol. 4 No. 4, pp.331 - 341.

Schiuma, G. and Lerro, A. (2011) 'Editorial: Knowledge-based dynamics for local development - a position paper', International Journal of Knowledge-Based Development, Vol. 2 No. 1 , pp. $1-15$.

Selviaridis, K. and Norrman, A. (2014) 'Performance-based contracting in service supply chains: a service provider risk perspective', Supply Chain Management: An International Journal, Vol. 19 No. 2, pp.153 - 172.

Serenko, A. and Bontis, N. (2011) 'Practical relevance of knowledge management and intellectual capital scholarly research: Books as knowledge translation agents', Knowledge and Process Management, Vol. 18 No. 1, pp.1 - 9.

Spender, J.C. (1996) 'Making Knowledge the Basis of a dynamic theory of the firm', Strategic Management Journal, 17(Special Issue: Knowledge and the Firm), pp.45 - 62. 
Staats, B.R. and Upton, D.M. (2011) 'Lean Knowledge Work', Harvard Business Review, Vol. 89 No. 10, pp.100 - 110.

Starbuck, W.H. (1992) 'Learning by Knowledge-Intensive Firms', Journal of Management Studies, Vol. 29 No. 6, pp.713 - 740.

Sveiby, K.E. (1997) The New Organizational Wealth. Managing \& Measuring KnowledgeBased Assets, Berret-Koehler Publishers, Inc., San Francisco.

Tarn, D. (2005) 'Marketing-based tangibilisation for services', The Service Industries Journal, Vol. 25 No. 6, pp. 747 - 772.

Tomé, E. (2014) 'Editorial to the Special Issue on Managing Services in the Knowledge Economy: a Challenge for the 21 st Century', International Journal of Knowledge-Based Development, Vol. 5 No. 1, pp.1 - 4.

van Wijk, R., Jansen, J.P. and Lyles, M.A. (2008) 'Inter- and intra-organizational knowledge transfer: a meta-analytic review and assessment of its antecedents and consequences', Journal of Management Studies, Vol. 45 No. 4, pp.815 - 838.

Vargo, S.L., Maglio, P.P. and Akaka, M.A. (2008) 'On value and value co-creation: A service systems and service logic perspective', European Management Journal, Vol. 26 No. 3, pp. 145 - 152.

Vargo, S.L. and Lusch, R.F. (2004) 'Evolving to a new dominant logic for marketing', Journal of Marketing, Vol. 68 No. 1, pp.1 - 17.

von Nordenflycht, A. (2010) 'What is a Professional Service Firm? Toward a Theory and Taxonomy of Knowledge-Intensive Firms', Academy of Management Review, Vol. 35 No. 1, pp. 155 - 174.

Walsh, J. N. (2014) 'The sharing and transfer of context specific knowledge in a product support environment', International Journal of Knowledge-Based Development, Vol. 5 No. 1, pp.80 $-97$.

Wiig, K.M. (1997) 'Knowledge Management: An Introduction and Perspective', Journal of Knowledge Management, Vol. 1 No. 1, pp.6 - 14.

Winch, G. and Schneider, E. (1993) 'Managing the Knowledge-Based Organization: The Case of Architectural Practice', Journal of Management Studies, Vol. 30 No. 6, pp.923 - 937.

Windrum, P. and Tomlinson, M. (1999) 'Knowledge-intensive Services and International Competitiveness: A Four Country Comparison', Technology Analysis \& Strategic Management, Vol. 11 No. 3, pp.391 - 408.

Yigitcanlar, T. (2011) 'Redefining knowledge-based urban development', International Journal of Knowledge Based Development, Vol. 2 No. 4, pp.340 - 356. 
- How to demonstrate the value of the intangible service outputs?

- How to extend managerial practices to the customer and the service network?

- What are the most important knowledge assets?

- How to acquire and develop them further?

- What is the business model for transforming the assets into valuable services?

\section{Service value network}

Knowledge-intensive organization

Knowledge worker \& team
Value co-

creation

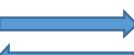

Active

participation
Customer

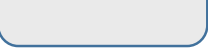

- How to guide and motivate autonomous knowledge workers?

- How to provide a working environment that facilitates efficient and effective work?

Figure 1. Summary of the literature: key management issues in knowledge-intensive organizations. 